\title{
Uncommon location of pilomatrixoma: the scrotal skin
}

\section{Mohammed Chaouche, Younes Barbach, Abdellah Dah Cherif, Sara Elloudi, Hanane Baybay, Fatima Zahra Mernissi}

Department of Dermatology and Venereology, University Hospital Hassan II, Fez, Morocco

Corresponding author: Dr. Mohammed Chaouche, E-mail: medch11@hotmail.com

Pilomatrixoma, calcifying epithelioma of Malherbe, is a cutaneous tumor, originating from the hair matrix, is characterized as a common, slowly growing benign cutaneous tumour that appears generally within the first decades of life [1]. A 52-year-old man, without history, has developed a scrotal, nodular firm tumor, measuring $15 \mathrm{~mm}$ (Fig. 1). Most often, its preoperative diagnosis is not possible, because of its clinical

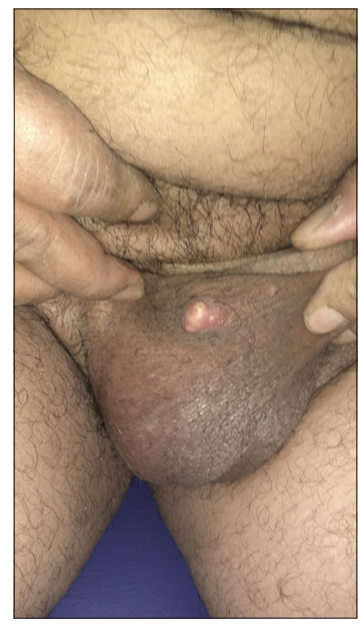

Figure 1: Location of pilomatrixoma on the scrotal skin. polymorphism. The precise diagnosis is histological, by the revealing of mummified cells. The treatment is surgical, with only purpose to perform complete removal of pathologic tissue, allowing to decrease the rate of local relapse [2].

\section{Consent}

The examination of the patient was conducted according to the Declaration of Helsinki principles.

\section{REFERENCES}

1. Pulvermacker B, Seroussi D, Haddad R, Mitrofanoff M. Pilomatricoma or calcifying epithelioma of Malherbe. A pediatric review of 89 cases. Ann Chir Plast Esthet. 2007;52:39-42.

2. Minkowitz G, Lee M, minkowitz S. Pilomatricoma of the testicle. An ossifying testicular tumor with hair matrix differentiation. Arch Pathol Lab Med. 1995;119:96-9.

Copyright by Mohammed Chaouche, et al. This is an open-access article distributed under the terms of the Creative Commons Attribution License, which permits unrestricted use, distribution, and reproduction in any medium, provided the original author and source are credited.

Source of Support: Nil, Conflict of Interest: None declared.

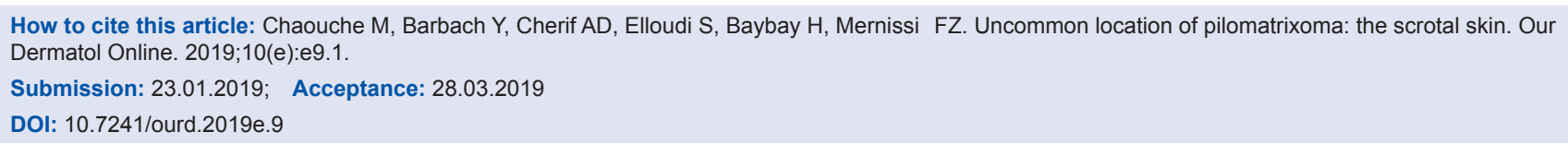

